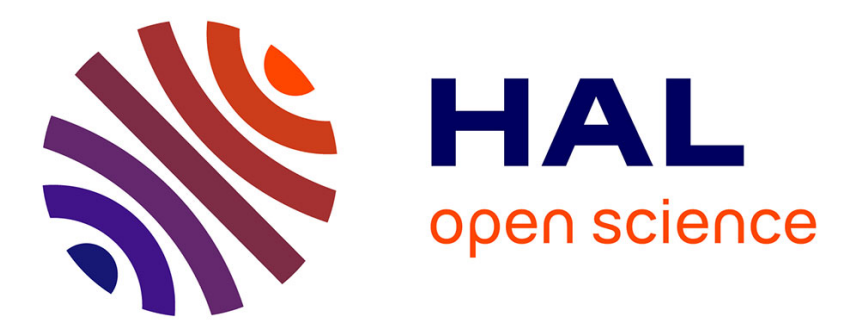

\title{
Additive effects of levonorgestrel and ethinylestradiol on brain aromatase (cyp19a1b) in zebrafish specific in vitro and in vivo bioassays
}

N. Hinfray, C. Tebby, C. Garoche, B. Piccini, G. Bourgine, S. Ait-Aissa, O. Kah, Farzad Pakdel, F. Brion

\section{To cite this version:}

N. Hinfray, C. Tebby, C. Garoche, B. Piccini, G. Bourgine, et al.. Additive effects of levonorgestrel and ethinylestradiol on brain aromatase (cyp19a1b) in zebrafish specific in vitro and in vivo bioassays. Toxicology and Applied Pharmacology, 2016, 307, pp.108-114. 10.1016/j.taap.2016.07.023 . hal01367151

HAL Id: hal-01367151

https://hal-univ-rennes1.archives-ouvertes.fr/hal-01367151

Submitted on 19 Feb 2018

HAL is a multi-disciplinary open access archive for the deposit and dissemination of scientific research documents, whether they are published or not. The documents may come from teaching and research institutions in France or abroad, or from public or private research centers.
L'archive ouverte pluridisciplinaire HAL, est destinée au dépôt et à la diffusion de documents scientifiques de niveau recherche, publiés ou non, émanant des établissements d'enseignement et de recherche français ou étrangers, des laboratoires publics ou privés. 
Additive effects of levonorgestrel and ethinylestradiol on brain aromatase (cyp19a1b) in zebrafish specific in vitro and in vivo bioassays

Hinfray $\mathrm{N}^{1^{*}}$, Tebby $\mathrm{C}^{2}$, Garoche $\mathrm{C}^{1}$, Piccini $\mathrm{B}^{1}$, Bourgine $\mathrm{G}^{3}$, Aït-Aïssa $\mathrm{S}^{1}$, Kah $\mathrm{O}^{3}$, Pakdel $\mathrm{F}^{4}$, Brion $\mathrm{F}^{1}$.

${ }^{1}$ INERIS, Unité d'écotoxicologie in vitro et in vivo, Verneuil-en-Halatte, France

${ }^{2}$ INERIS, Unité Modèles pour 1'Ecotoxicologie et la Toxicologie, Verneuil-en-Halatte,

France

${ }^{3}$ IRSET, équipe NEED, Université de Rennes 1, Rennes, France

${ }^{4}$ IRSET, Inserm U1085, équipe TREC, Université de Rennes 1, Rennes, France

* Corresponding author: nathalie.hinfray@ineris.fr 


\section{ABSTRACT}

Estrogens and progestins are widely used in combination in human medicine and both are present in aquatic environment. Despite the joint exposure of aquatic wildlife to estrogens and progestins, very little information is available on their combined effects. In the present study we investigated the effect of ethinylestradiol (EE2) and Levonorgestrel (LNG), alone and in mixtures, on the expression of the brain specific ER-regulated cyp19alb gene. For that purpose, recently established zebrafish-derived tools were used: (i) an in vitro transient reporter gene assay in a human glial cell line (U251-MG) co-tranfected with zebrafish estrogen receptors (zfERs) and the luciferase gene under the control of the zebrafish cyp19alb gene promoter and (ii) an in vivo bioassay using a transgenic zebrafish expressing GFP under the control of the zebrafish cyp19alb gene promoter (cyp19alb-GFP). Concentrationresponse relationships for single chemicals were modeled and used to design the mixture experiments following a ray design. The results from mixture experiments were analyzed to predict joint effects according to concentration addition and statistical approaches were used to characterize the potential interactions between the components of the mixtures (synergism/antagonism). We confirmed that some progestins could elicit estrogenic effects in fish brain. In mixtures, EE2 and LNG exerted additive estrogenic effects both in vitro and in vivo, suggesting that some environmental progestin could exert effects that will add to those of environmental (xeno-)estrogens. Moreover, our zebrafish specific assays are valuable tools that could be used in risk assessment for both single chemicals and their mixtures.

KEYWORDS: levonorgestrel, ethinylestradiol, mixture, brain aromatase, transgenic zebrafish, U251-MG cells 
GRAPHICAL ABSTRACT

Effect of mixtures of estrogens and progestins on central nervous system? Ethynilestradiol [EE2)

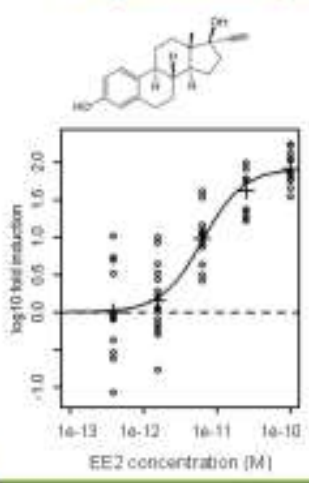
In vitro assay

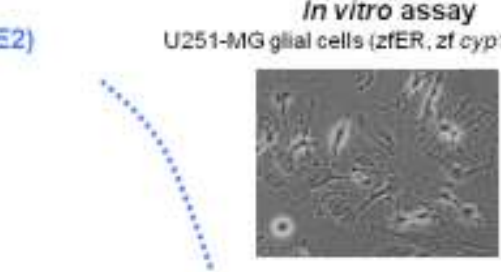

In vivo assay cyp19a1b-GFP zebrafishembryos
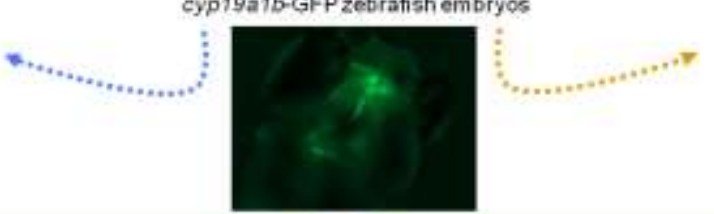

Levonorgestrel (LNG)

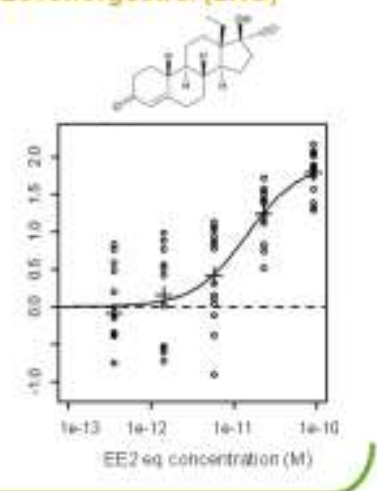

Experimental plan for mixtures of EE2 and LNG

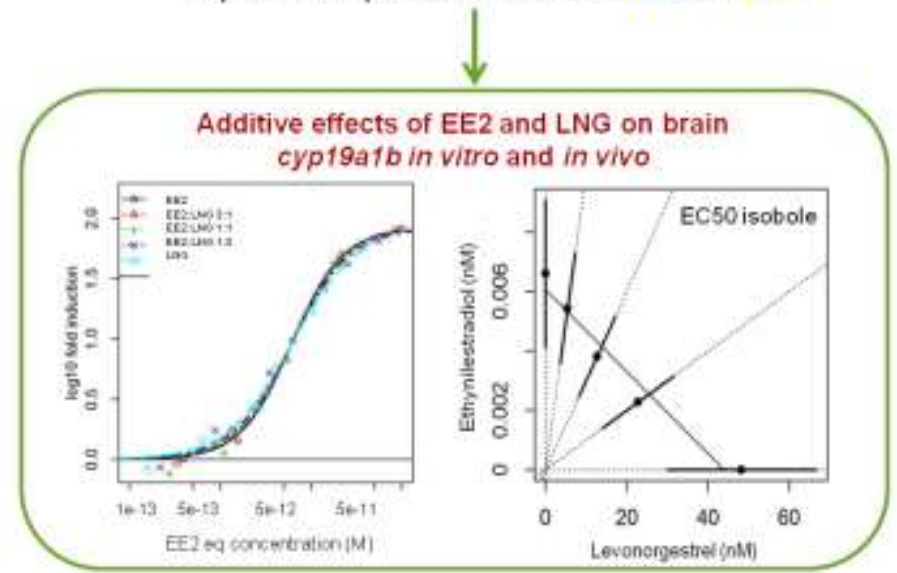




\section{HIGHLIGHTS}

- Combined effects of EE2 and LNG were assessed on ER-dependent cyp19alb expression

- EE2 and LNG alone induced brain aromatase in zebrafish specific bioassays

- Experimental ray design allowed complete concentration-response surfaces modeling

- EE2 and LNG exerted additive effects on brain aromatase in radial glial cells 


\section{INTRODUCTION}

Endocrine disrupting chemicals (EDCs) have been extensively studied during the last decade due to their adverse effects on aquatic organism reproduction and development. To date, most attention on EDCs has been focused on compounds able to interact with the estrogen receptors (ERs). The occurrence, fate and effects of both natural and synthetic estrogens (estradiol (E2), estriol, estrone and ethinylestradiol (EE2)) and estrogen-like compounds are now well documented. As estrogens can be found in mixtures in the aquatic environment, a number of studies evaluated the effects of their combined exposure on estrogen signaling in aquatic organisms. Results from these studies demonstrate that binary or multi-component mixtures of ER agonists generally act in an additive manner on the expression of ER-regulated genes in both brain and liver (Thorpe et al. 2001, Rajapakse et al. 2004, Lin and Janz 2006, Kortenkamp 2007, Petersen and Tollefsen 2011, Brion et al. 2012, Petersen et al. 2013). In some cases, some deviations from additivity can be observed, especially with infra-additive effects, both in in vitro and in vivo experiments (Rajapakse et al. 2004, Lin and Janz 2006, Petersen and Tollefsen 2011, Petersen et al. 2013).

Estrogens and progestins are widely used in combination in human medicine, especially in oral contraceptives and hormone replacement therapy (Zeilinger et al. 2009). Their extensive use and poor removal by sewage treatment plants have led to contamination of the aquatic environment (Besse and Garric 2009, Liu et al. 2011). However, compared to estrogens, the occurrence, fate and effects of progestins were poorly studied. They are found in effluents and in surface waters (rivers, lakes, streams) and ground waters at concentrations up to tens of $\mathrm{ng} / \mathrm{L}$, but also in sediments from rivers at concentrations up to tens of $\mathrm{ng} / \mathrm{g}$ (for review see (Besse and Garric 2009, Liu et al. 2011, Fent 2015). Moreover, progestins are potent developmental and reproductive toxicants for aquatic organisms (for review see 
Zeilinger et al. 2009, Kumar et al. 2015). Among these progestins, levonorgestrel (LNG) is a synthetic progestin structurally related to testosterone (19-Nortestosterone derivative), used alone or in association with an estrogen such as ethinylestradiol for contraception purposes (emergency contraceptives or birth control pills). LNG has been detected in some effluents, sediments, ground water, tap water, but also in surface water of rivers at concentrations up to 38 ng/L (Vulliet et al. 2008, Besse and Garric 2009, Al-Odaini et al. 2010, Liu et al. 2011, Vulliet and Cren-Olivé 2011, Fent 2015). LNG exerts biological activities that differ from the natural progestin (progesterone) since it has progestagenic and androgenic activities (Besse and Garric 2009) and also estrogenic activities both in vitro and in vivo (Jeng et al. 1992, Brion et al. 2012, Zucchi et al. 2012, Creusot et al. 2014, Kroupova et al. 2014). However, despite the joint exposure of aquatic wildlife to estrogens and progestins, very little information is available on their combined toxicity (Runnalls et al. 2015, Säfholm et al. 2015).

This study aims at investigating the effects of single and combined exposure to EE2 and LNG on the expression of the zebrafish cyp19alb gene both in in vitro and in vivo models. In zebrafish, the cyp19alb gene encodes the brain form of aromatase (aromatase B) which is only expressed in radial glial cells that act as neuronal progenitors both in developing and adult brain (Pellegrini et al. 2007). The cyp19alb gene is extremely sensitive to (xeno)estrogens and this regulation is ER-dependent (Le Page et al. 2008, Brion et al. 2012). In the past few years, we developed both in vitro and in vivo bioassays, based on zebrafish cyp19alb gene, that were used in this study: i) a human glial cell culture (U251-MG) co-transfected with zebrafish ER subtypes (zfER $\alpha, z f E R \beta 1$ and $z f E R \beta 2)$ and a luciferase gene under the control of the zebrafish cyp19alb promoter (Le Page et al. 2006), ii) a transgenic zebrafish (cyp19alb-GFP) line expressing GFP under the control of the zebrafish cyp19alb promoter which is suitable to detect estrogenicity of chemicals alone and in mixtures (Brion et al. 2012, 
Petersen et al. 2013). These in vivo and in vitro bioassays were used to assess the estrogenic responses of EE2 and LNG in mixtures; responses that were modeled using the concentrationaddition (CA) prediction model. Deviations from this no-interaction model were characterized in terms of synergism or antagonism, modeled using Jonker's interaction terms (Jonker et al. 2005) and their significance was tested. By this approach, the present study reports additive estrogenic effects of EE2 and LNG in mixtures on the expression of an estrogen-regulated gene in a glial cell context.

\section{MATERIAL AND METHODS}

\section{Chemicals}

EE2 (purity $\geq 98 \%$, CAS number: 57-63-6; reference: E4876) and LNG (purity $\geq$ 98\%; CAS number: 797-63-7; reference: N2260) were purchased from Sigma-Aldrich (SaintQuentin Fallavier, France).

\section{Zebrafish maintenance and breeding}

Animal culture, handling and experimentation were approved by the INERIS life science ethics committee and in accordance with French ethical laws. The cyp19alb-GFP transgenic zebrafish (Tong et al. 2009) were held at the Institut National de l'Environnement Industriel et des Risques (INERIS, Verneuil-en-Halatte, France). They were maintained in 3.5 $\mathrm{L}$ aquaria in a recirculation system (Zebtec, Tecniplast, Buguggiate, Italy) on a $14 \mathrm{~h}$ light: 10 $\mathrm{h}$ dark cycle at a temperature of $25.1 \pm 1.0^{\circ} \mathrm{C}$. They were allowed to reproduce (ratio of 2 
males for 1 female). Fertilized eggs were harvested and disinfected $5 \mathrm{~min}$ in water supplemented with $0.1 \%$ of commercial bleach ( $2.6 \%$ of sodium hypochlorite).

\section{Zebrafish exposure to EDCs}

Fertilized cyp19alb-GFP transgenic zebrafish eggs were exposed to chemicals (alone or in mixtures) or to solvent control (DMSO, 0.02\% v/v) according to (Brion et al. 2012) with minor modifications. Briefly, for each experimental condition, 20 embryos were exposed in $100 \mathrm{ml}$ of water. Embryos were kept at $28^{\circ} \mathrm{C}$, under semi-static conditions. Exposures were performed from 0 days post fertilization (dpf) to $4 \mathrm{dpf}$ without water renewal. At the end of the exposure period (96 hours), non-transgenic zebrafish were removed and 4-dpf old transgenic zebrafish were processed for fluorescence measurement by image analysis. Experiments were performed in accordance with European Union regulations concerning the protection of experimental animals (Directive 2010/63/UE).

\section{In vivo imaging}

In vivo fluorescence imaging was performed according to (Brion et al. 2012). Each live cyp19alb-GFP transgenic embryo was photographed once in dorsal view using a Zeiss AxioImager Z1 fluorescence microscope equipped with an AxioCam Mrm camera (Zeiss GmbH, Göttingen, Germany). Each photograph was acquired under the same exposure conditions (X10 objective, $134 \mathrm{~ms}$ of fluorescent light exposure, maximal light intensity). Fluorescence quantification was performed using Image $\mathbf{J}$ software (available at: http://rsb.info.nih.gov/ij/). For each picture, the integrated density (IntDen) was measured, i.e. 
the sum of the grey-values of all the pixels within the region of interest. All grey-values of 300 or less were defined as background values.

\section{U251-MG cell bioassay}

The ER-negative human glial cell line U251-MG (ECACC) culture, handling and the luciferase assay were performed according to (Le Page et al. 2006).

$\mathrm{U} 251-\mathrm{MG}$ cells were maintained at $37^{\circ} \mathrm{C}$ in $5 \% \mathrm{CO} 2$ atmosphere in phenol red-free Dulbecco's Modified Eagle's Medium (DMEM-F12, Sigma-Aldrich, St Louis, MO, USA) supplemented with $8 \%$ fetal calf serum (FCS), $2 \mathrm{mM}$ L-glutamine, $20 \mathrm{U} / \mathrm{mL}$ penicillin, 20 $\mu \mathrm{g} / \mathrm{mL}$ streptomycin and $50 \mathrm{ng} / \mathrm{mL}$ amphotericin B.

For transfection experiments, U251-MG cells were plated in 24-well plates at a density of $0.2 \times 10^{5}$ cells $/ \mathrm{ml}$. After 24 hours, the medium was replaced with fresh phenol red-free DMEM containing $2 \%$ FCS. In each well, $25 \mathrm{ng}$ of zfER expression vector (i.e. Topo-pcDNA3 expression vector containing the coding region of zfER $\alpha$ or zfER $\beta 2$ complementary DNA and the neomycin resistance gene (Menuet et al. 2002)), $25 \mathrm{ng}$ of cytomegalovirus- $\beta$-galactosidase control plasmid and $150 \mathrm{ng}$ of luciferase reporter construct (i.e. proximal promoter region of the zebrafish cyp19a1b gene coupled to the luciferase reporter gene (Menuet et al. 2005)) were transfected using JetPEI ${ }^{\mathrm{TM}}$ reagent, as indicated by the manufacturer (Polyplustransfection, France). After one night, medium was replaced with fresh DMEM-F12 containing $2 \%$ charcoal/dextran FCS with xeno-estrogens or vehicle (DMSO, $0.1 \% \mathrm{v} / \mathrm{v})$. The luciferase activities were assayed after $48 \mathrm{~h}$ using the luciferase assay system (Promega). $\beta$ galactosidase activity was used to normalize transfection efficiency in all experiments. Results were expressed as fold induction relative to the solvent. 


\section{Data normalization}

In the in vivo assay with cyp19alb-GFP transgenic zebrafish, induction of GFP fluorescence was measured as IntDen and normalized by dividing by the geometric mean of the IntDen in the DMSO control group. In the preliminary single chemical experiments used for the design of mixture experiments, the concentration-response relationships were obtained in separate experiments. For that reason, the log-inductions were further normalized by the logarithm of the geometric mean of the positive controls (EE2; 0.05nM), which corresponds to a maximum response level.

In the in vitro assay with U251-MG cell cultures, the data were normalized by dividing by the geometric mean of the corresponding solvent control group. EE2 and levonorgestrel as single chemicals were tested on the same plate therefore no additional normalization was required.

\section{Concentration-response modeling}

The relationship between concentration and log-induction was modeled with a 3parameter Hill model, where the basal level was set to 0:

$$
\Phi(c)=\frac{\operatorname{Max}}{1+\left(\frac{c}{E C 50}\right)^{\beta}}
$$

where Max is the maximum level of induction, $c$ is the concentration, EC50 is the concentration producing $50 \%$ of the maximum induction, and $\beta$ is the Hill slope. In both in vivo and in vitro single chemical experiments, common values of Max and $\beta$ were estimated for EE2 and levonorgestrel. Lack-of-fit F-tests were performed to check the model fit compared to an analysis of variance, and to check that the model did not fit less well with 
common values for both compounds. The parameters were estimated by least squares, using $\mathrm{R}$ 3.1.1 (R Core Team 2014) and package drc (Ritz and Streibig 2005).

\section{Mixture experimental designs}

Preliminary single chemical experiments were performed in order to construct the mixture experimental designs.

In the in vivo assay, three concentration-response datasets for EE2 and two concentration-response datasets for levonorgestrel were used. Each concentration-response was successfully modeled with the Hill model and common values for the maximum response level and the slope were successfully estimated. These models were used to build a ray design with single chemicals and three mixture ratios $(3: 1,1: 1$, and $1: 3$ in terms of relative toxicity quantified by the EC50), with five concentrations along each ray, centered around the EC50 with 4-fold dilutions (range of EE2 concentrations from $9.77 \times 10^{-8} \mu \mathrm{M}(28.9 \mathrm{pg} / \mathrm{L})$ to $1 \times 10^{-4}$ $\mu \mathrm{M}(29.6 \mathrm{ng} / \mathrm{L})$ and range of $\mathrm{LNG}$ concentrations from $0.293 \mathrm{nM}(91 \mathrm{ng} / \mathrm{L})$ to $0.3 \mu \mathrm{M}(93$ $\mu \mathrm{g} / \mathrm{L})$ ) (Supplemental Table 1). In theory, the equimolar mixture ratio is the one where interactions are likely to be most visible.

In the in vitro assay, one experiment with EE2 and levonorgestrel on the same plate was used to calibrate the design. With levonorgestrel, no response saturation was observed in the range of concentrations used to test for ER receptor activation. The maximum response and Hill slope were therefore imputed from the EE2 dose-response. The data were successfully modeled with the 3-parameter Hill model. Given that the levonorgestrel ray and likely some of the mixture rays would not be modeled with the 3-parameters Hill model independently from the rest of the data because of the absence of response saturation, a factorial design for the mixture experiment was preferred over a ray design. This was build 
with 3 levels of levonorgestrel $(0,1$, and $10 \mu \mathrm{M})$ and 6 levels of EE2 $(0,0.001 \mathrm{nM}$ to $10 \mathrm{nM}$ with 10-fold dilutions).

\section{Mixture concentration-response modeling}

Concentration-response surfaces were modeled with the concentration addition (CA) model (Loewe 1953) using Berenbaum's general solution (Berenbaum 1985). This CA model is only defined when all mixture components produce the same maximum response and when the basal response is equal. In view to model mixture experiment data with the CA model, several adjustments were performed. Since the data for single compounds were obtained from several independent experiments, they were normalized (data were divided by the geometric mean of the non-treated group) to be able to compare the concentration-responses curves. The single compound data were modeled with a null basal response without detriment to the modeling (F-test, $\mathrm{p}<0.05)$ and with no significant change of the EC50s. Then, common maximum responses were estimated. At present, there is still a discussion on the validity of the CA model when single compounds produce different slopes because this would suggest that the mode of action is different (Backhaus et al. 2004, Gennings et al. 2005): the concept of Toxic Equivalent Factor is a more restrictive version of CA (Webster 2013).. For that reason, when this was not detrimental to the model fit, a common slope was also estimated for single compounds. The only free remaining parameter was then the EC50. All these constraints do artificially slightly reduce the uncertainty round the EC50, but when they are not detrimental to the model fit, the estimation of the EC50 is not significantly affected by setting these three parameters (except for LNG in the U251-MG cells transfected with zfER $\beta 2$ where no saturation response was observed). 
Interaction terms for simple antagonism/synergy (SA), dose-ratio dependent interactions (DR), and dose-level dependent interactions (DL) were subsequently added to the CA model (Jonker et al. 2005). Significance of the interactions was assessed using approximate F-tests on the residual sums of squares by considering that the models were nested. Acceptability of the concentration-response surface models was assessed with a lackof-fit F-test compared to the analysis of variance model.

\section{RESULTS}

No effect due to chemical exposure was observed on lethality or time to hatch during any of the in vivo single chemical and mixture studies.

\section{In vitro effects of single test compounds}

The effect of EE2 and LNG alone was assessed in U251-MG glial cells co-transfected with zf-ERs and the Zf-cyp19alb promoter-luciferase reporter (one exposure experiment for each compound and each ER, 3 measure replicates for each condition). EE2 treatment induced expression of luciferase activity in a concentration-dependent manner, and EC50 (median effective concentration) of $1.4 \times 10^{-10} \mathrm{M}$ for $\mathrm{ER} \alpha$ and $6.63 \times 10^{-12} \mathrm{M}$ for ER $\beta 2$ were calculated (supplemental figure 1). LNG alone was poorly effective in inducing luciferase activity and no saturation of the response was observed. EC50s for LNG equal to $36.1 \times 10^{-6} \mathrm{M}$ for ER $\alpha$ and $12.6 \times 10^{-6} \mathrm{M}$ for ER $\beta 2$ were calculated in that in vitro model by assuming that the maximum response and the slope were equal to those of EE2.

\section{In vitro effects of binary mixtures of EE2 and LNG}


EC50 for EE2 and LNG were calculated from mixture experiments to confirm EC50 previously obtained in single test compounds experiments. EC50 for EE2 were $1.29 \times 10^{-10} \mathrm{M}$ and 1.19x $10^{-11} \mathrm{M}$ for U251-MG glial cells transfected with ER $\alpha$ and ER $\beta 2$ respectively. For LNG, EC50 were $22 \times 10^{-6} \mathrm{M}$ and $8.6 \times 10^{-6} \mathrm{M}$ for U251-MG glial cells transfected with ER $\alpha$ and ER $\beta 2$ respectively. All these EC50s are in the same range of order than those previously calculated in the single test compound experiments.

In vitro, mixtures of EE2 and LNG led to a concentration-dependent induction of luciferase activity in U251-MG cells transfected both with ER $\alpha$ and ER $\beta 2$ (Figure 1). The measured inductions of luciferase activity can be modeled by the CA model (lack-of-fit F-test compared to the analysis of variance model: $p=0.548$ for $E R \alpha$ and $p=0.164$ for ER $\beta 2$ ). None of the interactions added to the CA model improved the model fit significantly and using different slopes for both compounds in the CA model did not improve the model fit either (approximate F-test: $\mathrm{p}=0.44$ for $\mathrm{ER} \alpha$ and $\mathrm{p}=0.68$ for $\mathrm{ER} \beta 2$ ).

\section{In vivo effects of single test compounds}

Exposure of transgenic cyp19alb-GFP zebrafish to EE2 for $96 \mathrm{~h}$ led to a concentrationdependent induction of GFP expression, with an EC50 of $5.0 \times 10^{-12} \pm 1.2 \times 10^{-12} \mathrm{M}$ (Supplemental figure 2; 3 independent experiments with 8-19 transgenic zebrafish per condition). This expression of GFP is localized to radial glial cells of the brain (Figure 2). LNG alone also led to a concentration-dependent induction of GFP expression in radial glial cells of the brain with an EC50 of $1.68 \times 10^{-8} \mathrm{M} \pm 0.6 \times 10^{-8} \mathrm{M}$ (Supplemental figure 3; 2 independent experiments with 8-19 transgenic zebrafish per condition).

\section{In vivo effects of binary mixtures of EE2 and LNG}


In mixture experiment with transgenic cyp19alb-GFP zebrafish, EC50 were $6.18 \times 10^{-}$ ${ }^{12} \mathrm{M}$ for EE2 and $4.55 \times 10^{-8} \mathrm{M}$ for $\mathrm{LNG}$.

The mixtures of EE2 and LNG induced GFP expression in radial glial cells of the brain of transgenic cyp19alb-GFP zebrafish in a concentration-dependent manner (Figure 3). Observed responses were compared to the concentration-response surfaces modeled with the CA model with identical slopes for each compound (Loewe 1953). Observed responses were in good agreement with the CA model (lack-of-fit F-test compared to the analysis of variance model: $\mathrm{p}=1,00$ ) and no deviation of the EC50 isobole was observed (Figure 4). Interactions were then added to the CA model but none showed a significant improvement of the adjustment quality of the model (approximate F-tests: $\mathrm{p}=0.43$ for SA, $\mathrm{p}=0.82$ for DR and $\mathrm{p}=0.92$ for DL), indicating that EE2 and LNG exerted additive effects in mixture. Using different slopes for both compounds in the CA model did not improve the model fit either (approximate F-test: $\mathrm{p}=0.42$ ).

\section{DISCUSSION}

The synthetic estrogen EE2 showed a high estrogenic potency in vivo in transgenic cyp19alb-GFP zebrafish with an EC50 of $6.18 \times 10^{-12} \mathrm{M}(1.84 \mathrm{ng} / \mathrm{L})$ for the induction of GFP expression in the radial glial cells of the brain similar to previous studies using the same in vivo model (Brion et al. 2012, Petersen et al. 2013). In transgenic medaka stably expressing GFP under the control of the choriogenin gene promoter and in transgenic zebrafish stably expressing luciferase under the control of an ERE, EE2 was less potent (EC50s of 2.4x10- ${ }^{10}$ $\mathrm{M}(71.9 \mathrm{ng} / \mathrm{L})$ and of $1 \times 10^{-10} \mathrm{M}(296.4 \mu \mathrm{g} / \mathrm{L})$ respectively) than in the cyp19alb-GFP transgenic zebrafish, confirming the sensitivity of both the cyp19alb gene and the cyp19albGFP transgenic zebrafish line to synthetic estrogens (Legler et al. 2002, Brion et al. 2012, 
Spirhanzlova et al. 2016). In U251-MG cells transfected with ER $\alpha$ or ER $\beta 2$, EC50s are similar to those obtained using the same in vitro models in a previous study (Le Page et al. 2006) and to those calculated from the zfERs transactivation assays using human embryonic kidney cells (293HEK) cells (Legler et al. 2002). Both the in vitro (U251-MG cells transfected with ZfERs) and the in vivo (cyp19alb-GFP transgenic zebrafish) models proved to be suitable tools to detect estrogenic compounds as previously stated by (Le Page et al. 2006, Brion et al. 2012, Petersen et al. 2013).

Due to the potential risk LNG represents for aquatic organisms, numerous in vivo studies have been conducted the last few years to determine its negative impacts to non-target organisms, notably to fish and amphibian reproduction (for review see Kumar et al. 2015).

Studies on the effects of LNG in aquatic organisms focused essentially on peripheral reproductive organs, i.e. gonads and liver, while very few data are available on other target tissues such as the central nervous system. In vivo, in adult fish, LNG has clear androgenic effects since it induces spiggin production by the kidney in male and female sticklebacks (Svensson et al. 2013, Svensson et al. 2014) and also male secondary sexual characteristics in female fathead minnows (Zeilinger et al. 2009, Runnalls et al. 2013, Runnalls et al. 2015). On the other hand, information on the estrogenic effects of LNG in fish is scarce. For instance, effects of LNG on the expression of vitellogenin ( $v t g)$, a hepatic ER-regulated gene, are rather heterogeneous. While in adult female three-spined sticklebacks, an inhibition of vtg gene expression was observed in parallel to spiggin production induction after LNG exposure (Svensson et al. 2013), in male and female pubertal roach, LNG exposure led to an induction of vtg expression (Kroupova et al. 2014). The discrepancy between these studies may be attributed to the differences in LNG concentrations used (one order of magnitude higher in roach ( $3 \mu \mathrm{g} / \mathrm{L})$ as compared to three-spined stickleback), to the different developmental stages of the fish (adult three-spined stickleback vs pubertal roach), and to different 
metabolization/biotransformation capabilities between the two species. Nevertheless, in our study, LNG induced GFP expression in the brain of cyp19alb-GFP transgenic zebrafish after 4 days of exposure with an EC50 of $4.55 \times 10^{-8} \mathrm{M}(14.2 \mu \mathrm{g} / \mathrm{L})$, confirming our previous findings on the estrogenic potency of LNG (Brion et al. 2012, Cano-Nicolau et al., 2016). In zebrafish, exposure to $231.95 \mathrm{ng} / \mathrm{L}$ of LNG from 4 hours post fertilization (hpf) to $144 \mathrm{hpf}$ also led to a slight induction of $v$ tg expression (1.2 fold), supporting this estrogenic effect of LNG in zebrafish larvae (Zucchi et al. 2012).

In vitro, in the U251-MG cells transfected with zfERs and the luciferase gene under the control of the promoter of the cyp19alb gene, LNG stimulates luciferase activity both with zfER $\alpha\left(\right.$ EC50 of $\left.22 \times 10^{-6} \mathrm{M}\right)$ and zfER $\beta 2\left(\mathrm{EC} 50\right.$ of $\left.8.6 \times 10^{-6} \mathrm{M}\right)$. Moreover, the estrogenic effect of LNG is mediated by zfERs since luciferase induction is blocked by the addition of ICI 182-780, a pure ER antagonist (Cano-Nicolau et al., 2016). Only little information on the in vitro estrogenic potency of LNG is available in the literature. In the human breast cancer cells MCF-7 (expressing hER $\alpha$ ), LNG stimulates the ER-dependent growth of the cells, and this effect is blocked by an ER antagonist, ICI 164-384, demonstrating this effect is mediated by ERs (Jeng et al. 1992). In MELN cells (cells derived from the MCF-7 stably transfected with the luciferase gene under the control of an ERE), LNG induces the expression of luciferase with an EC20 of $6.4 \times 10^{-8} \mathrm{M}$ (Creusot et al. 2014) and an EC50 of $2 \times 10^{-7} \mathrm{M}$ (personal communication from N. Creusot). In zebrafish liver cell lines co-transfected with zfERs and the luciferase gene under the control of an ERE (ZELH-zfER) (Cosnefroy et al. 2012), LNG exerted EC50s of $4 \times 10^{-7} \mathrm{M}$ and $2 \times 10^{-7} \mathrm{M}$ for ER $\alpha$ and ER $\beta 2$ respectively (personal communication from S. Aït-Aïssa). The sensitivity differences between all these models clearly highlight the necessity of using fish specific models in risk assessment of chemicals for aquatic organisms. 
In mammals, while LNG does not bind to the ERs, its metabolites do and they seem to be responsible for the estrogenic effects observed (Lemus et al. 1992, Santillán et al. 2001, García-Becerra et al. 2002). In human cells, the estrogenic activity of LNG was attributed to its metabolite $3 \beta, 5 \alpha$-tetrahydro-LNG and is mainly mediated by hER $\alpha$ (García-Becerra et al.

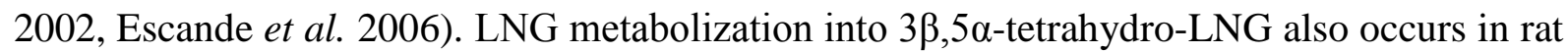
hypothalamus and pituitary (Larrea et al. 1987). Moreover, LNG does not bind to zebrafish ERs either (Cano-Nicolau et al., 2016), suggesting its conversion into estrogenic metabolites, especially in the brain. The differences of sensitivity to LNG of the different biological models (in vitro human with hERs or zfERs, in vitro fish, in vivo fish) could thus rely on differences in LNG metabolization capabilities of these different cell lines/organisms and on differences in binding affinity of metabolites to hERs and zfERs. Also, the possibility that these differences of sensitivity could rely on an ability of LNG to increase the levels of ERs expression in the brain of fish could not be ruled out. Nevertheless, our results clearly suggest that LNG (or its metabolites) could interact both with zfER $\alpha$ and zfER $\beta 2$. Altogether, our results give interesting information on the ability of LNG to interact with the zebrafish estrogenic pathway.

Given that simultaneous exposure to synthetic progestins and estrogens occurs in aquatic wildlife, information on mixture effect of these compounds is relevant. In the present study, we investigated the combined estrogenic effects of EE2 and LNG on the expression of the cyp19alb gene of zebrafish. The results show that EE2 and LNG exert additive effects on the expression of the zebrafish cyp19alb gene both in vivo and in vitro but with a better sensitivity of the cyp19alb-GFP transgenic zebrafish line compared to U251-MG cells. In vitro, in yeast cultures co-transfected with $\mathrm{hER} \alpha$ and the $\beta$-galactosidase under the control of an ERE, EE2 and different metabolites of LNG showed additive effects on the $\beta$-galactosidase activity while LNG alone had no effect (Santillán et al. 2001), reinforcing the idea that LNG 
estrogenicity is mediated by its metabolites. In fathead minnow, EE2 and LNG co-exposure reduced egg production in an additive manner while the increase of $v t g$ expression was only explained by exposure to EE2 with no contribution of LNG (Runnalls et al. 2015). In the same way, in the juvenile African clawed frog, no estrogenic effect of LNG alone or in mixture with EE2 is observed on the ER-regulated expression of vtg betal gene or on the sex ratio (Säfholm et al. 2015). All these studies show that additive mixture responses of EE2 and LNG do not occur on all ER-regulated endpoints in all tissues and, as previously stated by others, at all levels of biological organization (Runnalls et al. 2015, Säfholm et al. 2015).

In the present study, the effects of LNG alone or in combination are observed for quite high concentrations (high $\mathrm{ng} / \mathrm{L}$ range to low $\mu \mathrm{g} / \mathrm{L}$ range) as compared to environmental LNG concentrations (dozens of $\mathrm{ng} / \mathrm{L}$ ). Some endpoints were showed to be disturbed at lower concentrations such as reduced egg production in female fathead minnow after exposure to $0.8 \mathrm{ng} / \mathrm{L}$ for 21 days or masculinization of female zebrafish exposed to $10 \mathrm{ng} / \mathrm{L} \mathrm{LNG}$ during the process of sexual differentiation (0-63 dpf) (Zeilinger et al. 2009, Hua et al. 2015). However, LNG was showed to strongly bioconcentrate in fish since exposure to a water concentration of $1 \mathrm{ng} / \mathrm{L}$ of $\mathrm{LNG}$ gave rise to $\mathrm{ng} / \mathrm{ml}$ plasma concentrations in rainbow trout, exceeding the human therapeutic plasma concentration (Fick et al. 2010). Although the effective concentrations of LNG in the cyp19alb-GFP transgenic zebrafish line are higher than in other assays, it should be kept in mind that this bioassay allows the detection of the estrogenic effects of LNG after only $96 \mathrm{~h}$ of exposure in a simple and reliable in vivo assay. Moreover, the flexibility and space-saving character of this assay allows the assessment of a great number of conditions at the same time, ideal for complete experimental design needed for mixture testing. Thus, the cyp19alb-GFP transgenic zebrafish line clearly emerges as a relevant in vivo assay to assess the effect of mixtures of chemicals on the ER-signaling pathway at early critical developmental stages. And, although extrapolation from this assay to 
environmental scenarios is challenging, studies using the cyp19alb-GFP transgenic zebrafish line could possibly identify compounds/mixtures that will need further investigations in in vivo studies with more integrative endpoints.

In conclusion, in the present study we demonstrated (i) that our in vivo (cyp19albGFP transgenic zebrafish) biological model is a valuable tool that can be used in risk assessment for both single chemicals and their mixtures, (ii) the interest of employing complete experiment design models such as ray design to allow a better characterization of the effects of mixtures, even if no synergistic/antagonistic interaction was highlighted in mixtures of EE2 and LNG in our study, (iii) that EE2 and LNG in mixtures exert additive estrogenic effects both in vitro and in vivo, suggesting that some environmental progestins could exert effects that will add to those of environmental (xeno-)estrogens. Furthermore, the additive effects we observed on the expression of cyp19alb occurred at early life stages, for very short exposure duration time and located in radial glial cells that are progenitor cells of the brain. Our present work did not explore the potential adverse effects of these compounds alone and in mixture on the (neuro)development of zebrafish although these radial glial cells are known to play a crucial role in neurogenesis (Pellegrini et al. 2007, Diotel et al. 2013). Moreover, neurogenesis is affected by exposure to (xeno-)estrogens by means of a modulation of the neurogenic activity of these radial glial cells (Diotel et al. 2013). These considerations naturally argue in favor of further studies on the physiological consequences of these early perturbations of the cyp19alb gene expression on fish brain development.

\section{ACKNOWLEDGEMENT}

This work was supported by the French National Research Program on Endocrine Disruptors (PNRPE) from the French Ministry of Environment [MIXEZ program n ${ }^{\circ} 11-\mathrm{MRES}-\mathrm{PNRPE}-$ 
7-CVS-033] and the French National Research Agency [ANR; PROOFS program n ${ }^{\circ}$ ANR-13-

CESA-0006-03].

\section{REFERENCES}

Al-Odaini, N. A., M. P. Zakaria, M. I. Yaziz and S. Surif (2010). "Multi-residue analytical method for human pharmaceuticals and synthetic hormones in river water and sewage effluents by solid-phase extraction and liquid chromatography-tandem mass spectrometry." Journal of Chromatography A 1217(44): 6791-6806.

Backhaus, T., A. Arrhenius and H. Blanck (2004). "Toxicity of a mixture of dissimilarly acting substances to natural algal communities: predictive power and limitations of independent action and concentration addition." Environmental Science \& Technology 38(23): 6363-6370.

Berenbaum, M. C. (1985). "The expected effect of a combination of agents: the general solution." Journal of Theoretical Biology 114(3): 413-431.

Besse, J.-P. and J. Garric (2009). "Progestagens for human use, exposure and hazard assessment for the aquatic environment." Environmental Pollution 157(12): 3485-3494.

Brion, F., Y. Le Page, B. Piccini, O. Cardoso, S. K. Tong, B. C. Chung and O. Kah (2012). "Screening estrogenic activities of chemicals or mixtures in vivo using transgenic (cyp19a1b-GFP) zebrafish embryos." PLoS One 7(5): e36069.

Cano-Nicolau, J., C. Garoche, N. Hinfray, E. Pellegrini, N. Boujrad, F. Pakdel, O. Kah, F. Brion (2016). "Several synthetic progestins disrupt the glial cell specific-brain aromatase expression in developing zebrafish." Toxicology and Applied Pharmacology 305: 12-21.

Cosnefroy, A., F. Brion, E. Maillot-Marechal, J. M. Porcher, F. Pakdel, P. Balaguer and S. Ait-Aissa (2012). "Selective activation of zebrafish estrogen receptor subtypes by chemicals by using stable reporter gene assay developed in a zebrafish liver cell line." Toxicological Sciences 125(2): 439-449.

Creusot, N., S. Ait-Aissa, N. Tapie, P. Pardon, F. Brion, W. Sanchez, E. Thybaud, J. M. Porcher and H. Budzinski (2014). "Identification of synthetic steroids in river water downstream from pharmaceutical manufacture discharges based on a bioanalytical approach and passive sampling." Environmental Science \& Technology 48(7): 3649-3657.

Diotel, N., C. Vaillant, C. Gabbero, S. Mironov, A. Fostier, M.-M. Gueguen, I. Anglade, O. Kah and E. Pellegrini (2013). "Effects of estradiol in adult neurogenesis and brain repair in zebrafish." Hormones and Behavior 63(2): 193-207.

Escande, A., A. Pillon, N. Servant, J.-P. Cravedi, F. Larrea, P. Muhn, J.-C. Nicolas, V. Cavaillès and P. Balaguer (2006). "Evaluation of ligand selectivity using reporter cell lines stably expressing estrogen receptor alpha or beta." Biochemical Pharmacology 71(10): 1459-1469.

Fent, K. (2015). "Progestins as endocrine disrupters in aquatic ecosystems: Concentrations, effects and risk assessment." Environment International 84: 115-130.

Fick, J., R. H. Lindberg, J. Parkkonen, B. Arvidsson, M. Tysklind and D. G. Larsson (2010). "Therapeutic levels of levonorgestrel detected in blood plasma of fish: results from screening rainbow trout exposed to treated sewage effluents." Environmental Science \& Technology 44(7): 2661-2666. 
García-Becerra, R., E. Borja-Cacho, A. J. Cooney, K. J. Jackson, A. E. Lemus, G. Pérez-Palacios and F. Larrea (2002). "The intrinsic transcriptional estrogenic activity of a non-phenolic derivative of levonorgestrel is mediated via the estrogen receptor-a." The Journal of Steroid Biochemistry and Molecular Biology 82(4-5): 333-341.

Gennings, C., W. H. Carter, Jr., R. A. Carchman, L. K. Teuschler, J. E. Simmons and E. W. Carney (2005). "A unifying concept for assessing toxicological interactions: changes in slope." Toxicological Sciences 88(2): 287-297.

Hua, J., J. Han, Y. Guo and B. Zhou (2015). "The progestin levonorgestrel affects sex differentiation in zebrafish at environmentally relevant concentrations." Aquatic Toxicology 166: 1-9.

Jeng, M. H., C. J. Parker and V. C. Jordan (1992). "Estrogenic potential of progestins in oralcontraceptivesto stimulate human breast cancer cell proliferation." Cancer Research 52(23): 65396546.

Jonker, M. J., C. Svendsen, J. J. Bedaux, M. Bongers and J. E. Kammenga (2005). "Significance testing of synergistic/antagonistic, dose level-dependent, or dose ratio-dependent effects in mixture dose-response analysis." Environmental Toxicology \& Chemistry 24(10): 2701-2713.

Kortenkamp, A. (2007). "Ten years of mixing cocktails: a review of combination effects of endocrinedisrupting chemicals." Environmental Health Perspectives 115 Suppl 1: 98-105.

Kroupova, H. K., A. Trubiroha, C. Lorenz, V. Contardo-Jara, I. Lutz, R. Grabic, M. Kocour and W. Kloas (2014). "The progestin levonorgestrel disrupts gonadotropin expression and sex steroid levels in pubertal roach (Rutilus rutilus)." Aquatic Toxicology 154(0): 154-162.

Kumar, V., A. C. Johnson, A. Trubiroha, J. Tumova, M. Ihara, R. Grabic, W. Kloas, H. Tanaka and H. K. Kroupova (2015). "The Challenge Presented by Progestins in Ecotoxicological Research: A Critical Review." Environmental Science \& Technology 49(5): 2625-2638.

Larrea, F., F. Vilchis, B. Chavez, A. E. Perez, J. Garzaflores and G. Perezpalacios (1987). "The metabolism of 19-Nor contraceptive progestins modulates their biological activity at the neuroendocrine level." Journal of Steroid Biochemistry and Molecular Biology 27(4-6): 657-663.

Le Page, Y., A. Menuet, O. Kah and F. Pakdel (2008). "Characterization of a cis-acting element involved in cell-specific expression of the zebrafish brain aromatase gene." Molecular Reproduction and Development 75(10): 1549-1557.

Le Page, Y., M. Scholze, O. Kah and F. Pakdel (2006). "Assessment of xenoestrogens using three distinct estrogen receptors and the zebrafish brain aromatase gene in a highly responsive glial cell system." Environmental Health Perspectives 114(5): 752-758.

Legler, J., L. M. Zeinstra, F. Schuitemaker, P. H. Lanser, J. Bogerd, A. Brouwer, A. D. Vethaak, P. De Voogt, A. J. Murk and B. Van der Burg (2002). "Comparison of in vivo and in vitro reporter gene assays for short-term screening of estrogenic activity." Environmental Science \& Technology 36(20): 4410-4415.

Lemus, A. E., F. Vilchis, R. Damsky, B. A. Chavez, G. A. Garcia, I. Grillasca and G. Perez-Palacios (1992). "Mechanism of action of levonorgestrel: in vitro metabolism and specific interactions with steroid receptors in target organs." Journal of Steroid Biochemistry and Molecular Biology 41(3-8): 881-890.

Lin, L. L. and D. M. Janz (2006). "Effects of binary mixtures of xenoestrogens on gonadal development and reproduction in zebrafish." Aquatic Toxicology 80(4): 382-395.

Liu, Z.-h., J. A. Ogejo, A. Pruden and K. F. Knowlton (2011). "Occurrence, fate and removal of synthetic oral contraceptives (SOCs) in the natural environment: A review." Science of The Total Environment 409(24): 5149-5161. 
Loewe, S. (1953). "The problem of synergism and antagonism of combined drugs." Arzneimittelforschung 3(6): 285-290.

Menuet, A., E. Pellegrini, I. Anglade, O. Blaise, V. Laudet, O. Kah and F. Pakdel (2002). "Molecular characterization of three estrogen receptor forms in zebrafish: binding characteristics, transactivation properties, and tissue distributions." Biology of Reproduction 66(6): 1881-1892.

Menuet, A., E. Pellegrini, F. Brion, M. M. Gueguen, I. Anglade, F. Pakdel and O. Kah (2005). "Expression and estrogen-dependent regulation of the zebrafish brain aromatase gene." Journal of Comparative Neurology 485(4): 304-320.

Pellegrini, E., K. Mouriec, I. Anglade, A. Menuet, Y. Le Page, M. M. Gueguen, M. H. Marmignon, F. Brion, F. Pakdel and O. Kah (2007). "Identification of aromatase-positive radial glial cells as progenitor cells in the ventricular layer of the forebrain in zebrafish." Journal of Comparative Neurology 501(1): 150-167.

Petersen, K., E. Fetter, O. Kah, F. Brion, S. Scholz and K. E. Tollefsen (2013). "Transgenic (cyp19a1b-GFP) zebrafish embryos as a tool for assessing combined effects of oestrogenic chemicals." Aquatic Toxicology 138-139: 88-97.

Petersen, K. and K. E. Tollefsen (2011). "Assessing combined toxicity of estrogen receptor agonists in a primary culture of rainbow trout (Oncorhynchus mykiss) hepatocytes." Aquatic Toxicology 101(1): 186-195.

R Core Team (2014). R: A Language and Environment for Statistical Computing, R Foundation for Statistical Computing.

Rajapakse, N., E. Silva, M. Scholze and A. Kortenkamp (2004). "Deviation from additivity with estrogenic mixtures containing 4-nonylphenol and 4-tert-octylphenol detected in the E-SCREEN assay." Environmental Science \& Technology 38(23): 6343-6352.

Ritz, C. and J. C. Streibig (2005). "Bioassays analysis usin R." Journal of Statistical Software 12(5): 122.

Runnalls, T. J., N. Beresford, S. Kugathas, L. Margiotta-Casaluci, M. Scholze, A. P. Scott and J. P. Sumpter (2015). "From single chemicals to mixtures - reproductive effects of levonorgestrel and ethinylestradiol on the fathead minnow." Aquatic Toxicology 169: 152-167.

Runnalls, T. J., N. Beresford, E. Losty, A. P. Scott and J. P. Sumpter (2013). "Several synthetic progestins with different potencies adversely affect reproduction of fish." Environmental Science \& Technology 47(4): 2077-2084.

Säfholm, M., E. Jansson, J. Fick and C. Berg (2015). "Mixture Effects of Levonorgestrel and Ethinylestradiol: Estrogenic Biomarkers and Hormone Receptor mRNA Expression during Sexual Programming." Aquatic Toxicology 161: 146-153.

Santillán, R., G. Pérez-Palacios, M. n. Reyes, P. Damián-Matsumura, G. A. García, I. Grillasca and A. E. Lemus (2001). "Assessment of the oestrogenic activity of the contraceptive progestin levonorgestrel and its non-phenolic metabolites." European Journal of Pharmacology 427(2): 167-174.

Spirhanzlova, P., M. Leleu, A. Sébillot, G. F. Lemkine, T. Iguchi, B. A. Demeneix and A. J. Tindall (2016). "Oestrogen reporter transgenic medaka for non-invasive evaluation of aromatase activity." Comparative Biochemistry and Physiology Part C: Toxicology \& Pharmacology 179: 64-71.

Svensson, J., J. Fick, I. Brandt and B. Brunstrom (2013). "The Synthetic Progestin Levonorgestrel Is a Potent Androgen in the Three-Spined Stickleback (Gasterosteus aculeatus)." Environmental Science \& Technology 47(4): 2043-2051. 
Svensson, J., J. Fick, I. Brandt and B. Brunstrom (2014). "Environmental concentrations of an androgenic progestin disrupts the seasonal breeding cycle in male three-spined stickleback (Gasterosteus aculeatus)." Aquatic Toxicology 147: 84-91.

Thorpe, K. L., T. H. Hutchinson, M. J. Hetheridge, M. Scholze, J. P. Sumpter and C. R. Tyler (2001). "Assessing the biological potency of binary mixtures of environmental estrogens using vitellogenin induction in juvenile rainbow trout (Oncorhynchus mykiss)." Environmental Science \& Technology 35(12): 2476-2481.

Tong, S. K., K. Mouriec, M. W. Kuo, E. Pellegrini, M. M. Gueguen, F. Brion, O. Kah and B. C. Chung (2009). "A cyp19a1b-gfp (aromatase B) transgenic zebrafish line that expresses GFP in radial glial cells." Genesis 47(2): 67-73.

Vulliet, E. and C. Cren-Olivé (2011). "Screening of pharmaceuticals and hormones at the regional scale, in surface and groundwaters intended to human consumption." Environmental Pollution 159(10): 2929-2934.

Vulliet, E., L. Wiest, R. Baudot and M.-F. Grenier-Loustalot (2008). "Multi-residue analysis of steroids at sub-ng/L levels in surface and ground-waters using liquid chromatography coupled to tandem mass spectrometry." Journal of Chromatography A 1210(1): 84-91.

Webster, T. F. (2013). "Mixtures of endocrine disruptors: how similar must mechanisms be for concentration addition to apply?" Toxicology 313(2-3): 129-133.

Zeilinger, J., T. Steger-Hartmann, E. Maser, S. Goller, R. Vonk and R. Länge (2009). "Effects of synthetic gestagens on fish reproduction." Environmental Toxicology \& Chemistry 28(12): 2663-2670.

Zucchi, S., S. Castiglioni and K. Fent (2012). "Progestins and antiprogestins affect gene expression in early development in zebrafish (Danio rerio) at environmental concentrations." Environmental Science \& Technology 46(9): 5183-5192. 


\section{FIGURE CAPTIONS}

Figure 1: Concentration-response curves of luciferase activity in U251-MG cells transfected with ER $\alpha$ or ER $\beta 2$ after exposure to ethinylestradiol (EE2) alone or in combination with levonorgestrel (LNG) at different concentrations. All the data were modeled by fitting the concentration-addition model to the concentration-response surface. The points represent the triplicate of each measure.

Figure 2: In vivo imaging of 4-dpf old live transgenic cyp19a1b-GFP zebrafish embryos exposed to chemicals inducing GFP expression in radial glial cells. Dorsal view of the brain. For each chemical the concentration used is indicated. DMSO: dmso solvent control; EE2: ethinylestradiol; LNG: levonorgestrel.

Figure 3: Concentration-response curves of GFP in cyp19alb-GFP transgenic zebrafish after exposure to ethinylestradiol (EE2) and levonorgestrel (LNG) alone or in combinations (3 different ratios of substances). These data originated from the first exposure experiment and are representative of all the experiments performed. All the data were modeled by the concentration-addition model. Open circle represents one measure of GFP realized in one transgenic fish brain ( $\mathrm{n}=8-19$ fish per condition). In the last graphic (right, bottom) which gathers all the concentration-response curves, the points represent the means of the GFP experimentally measured.

Figure 4: Illustration of the EC50 for each ray of the ethinylestradiol + levonorgestrel mixtures. The points represent the EC50 and the bars represent the standard error. These data originated from the first exposure experiment with the cyp19a1a-GFP transgenic zebrafish line (described in figure 3) and are representative of all the experiments performed. 
Supplemental figure 1: Concentration-response curves of luciferase activity in U251-MG cells transfected with ER $\alpha$ or ER $\beta 2$ after exposure to ethinylestradiol (EE2) or levonorgestrel (LNG) alone at different concentrations. All the data were modeled by the 4 parameters loglogistic model both without any constraint (black dotted line) and with constraints applied on the max, the min and the slope (red line). The points represent the triplicate of each measure. The grey surfaces represent the $95 \%$ confidence intervals.

Supplemental figure 2: Concentration-response curves of GFP in cyp19alb-GFP transgenic zebrafish after exposure to ethinylestradiol (EE2) at different concentrations in three independent experiments. All the data were modeled by the 4 parameters log-logistic model both without any constraint (black dotted line) and with constraints applied on the max, the min and the slope (red line). Open circle represents one measure of GFP realized in one transgenic fish brain ( $\mathrm{n}=8-19$ fish per condition). The grey surfaces represent the 95\% confidence intervals.

Supplemental figure 3: Concentration-response curves of GFP in cyp19alb-GFP transgenic zebrafish after exposure to Levonorgestrel (LNG) at different concentrations in two independent experiments. All the data were modeled by the 4 parameters log-logistic model both without any constraint (black dotted line) and with constraints applied on the max, the min and the slope (red line). Open circle represents one measure of GFP realized in one transgenic fish brain ( $\mathrm{n}=6-12$ fish per condition). The grey surfaces represents the $95 \%$ confidence intervals. 
Figure 1

ERa

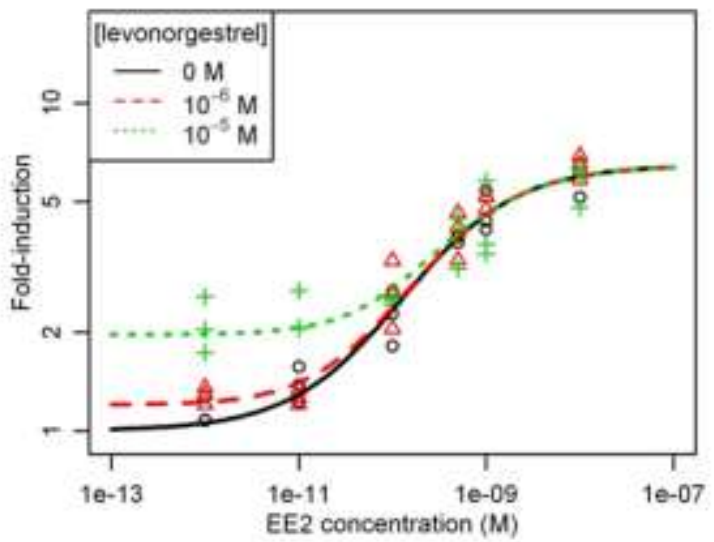

ERb2

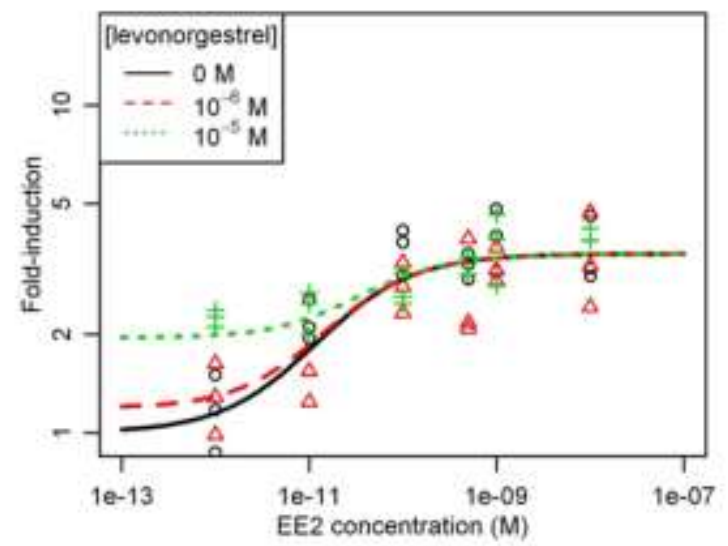


Figure 2

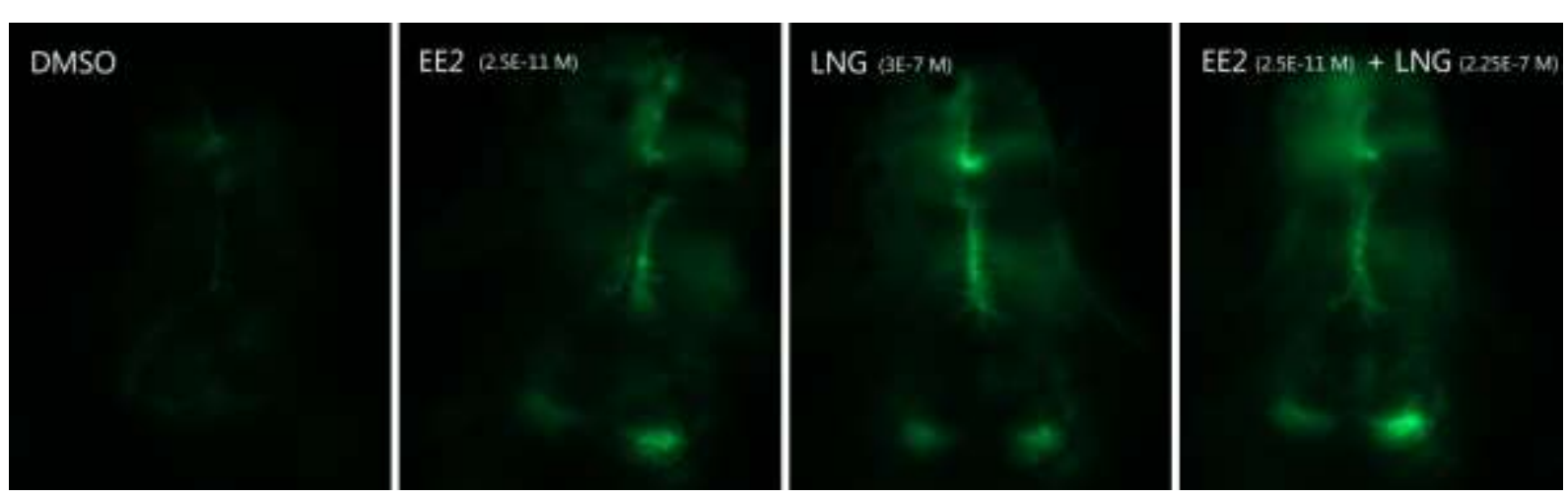


Figure 3
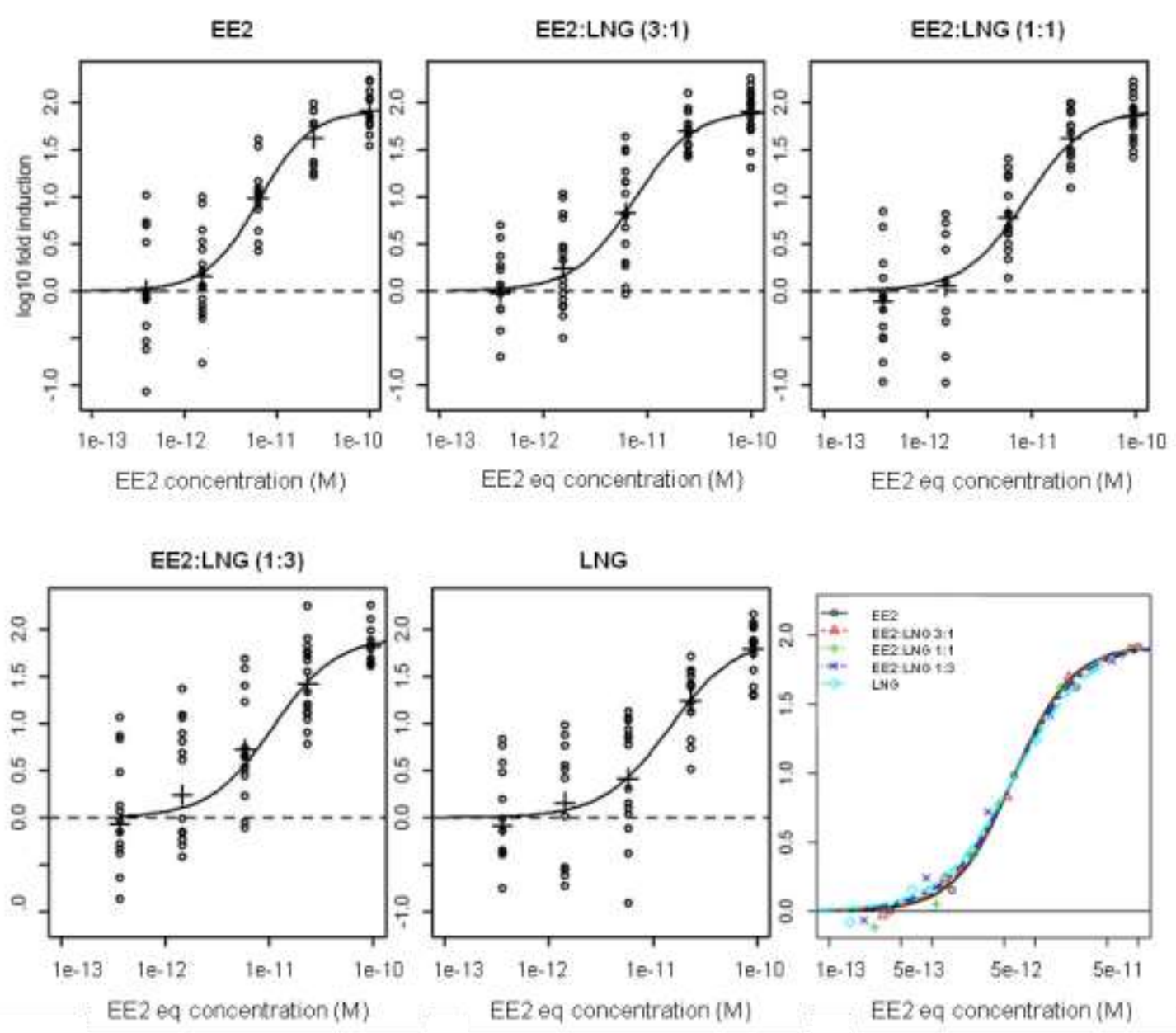
Figure 4

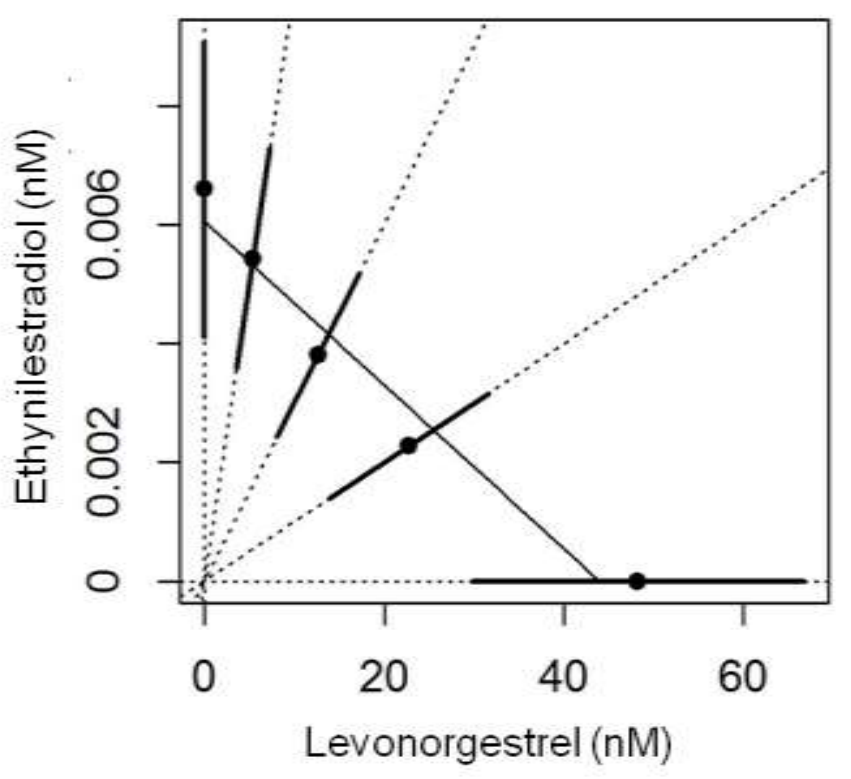


Supplemental figure 1

ERo

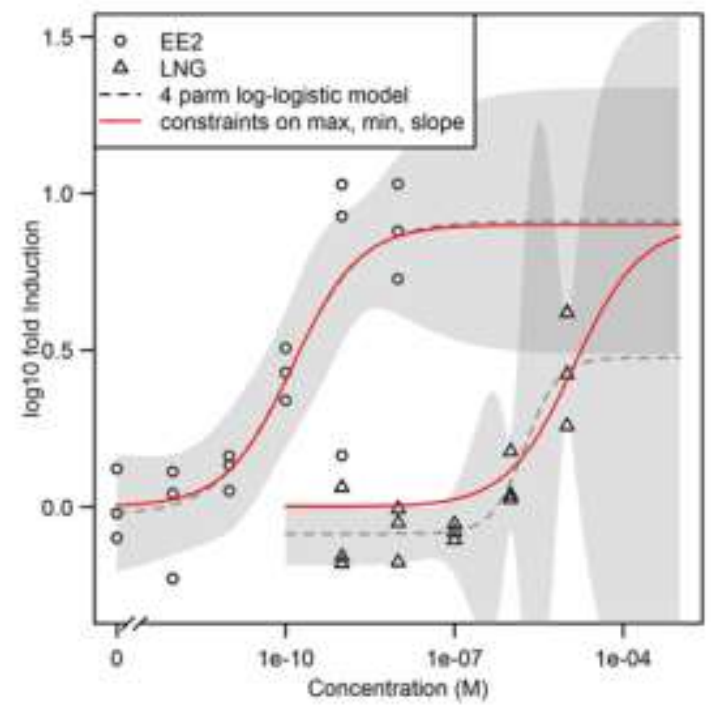

ERß2

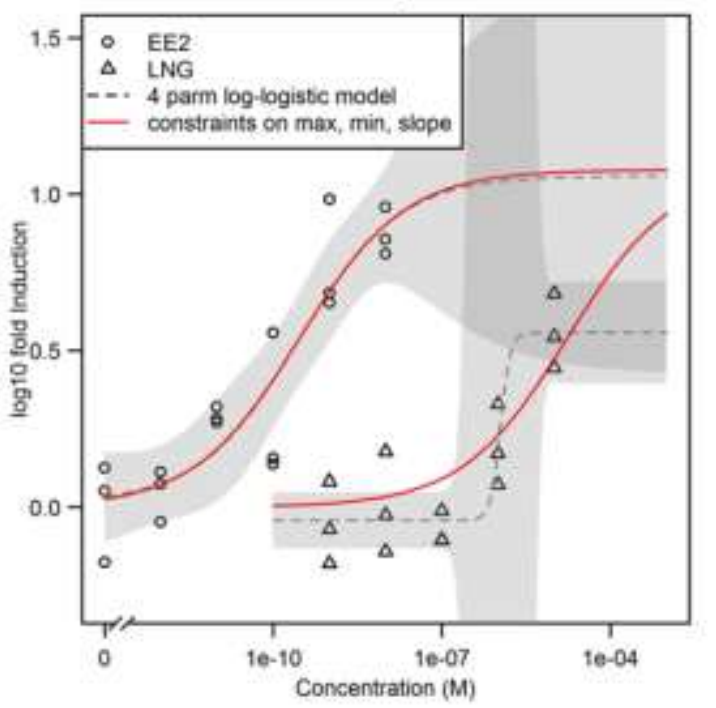


Supplemental figure 2
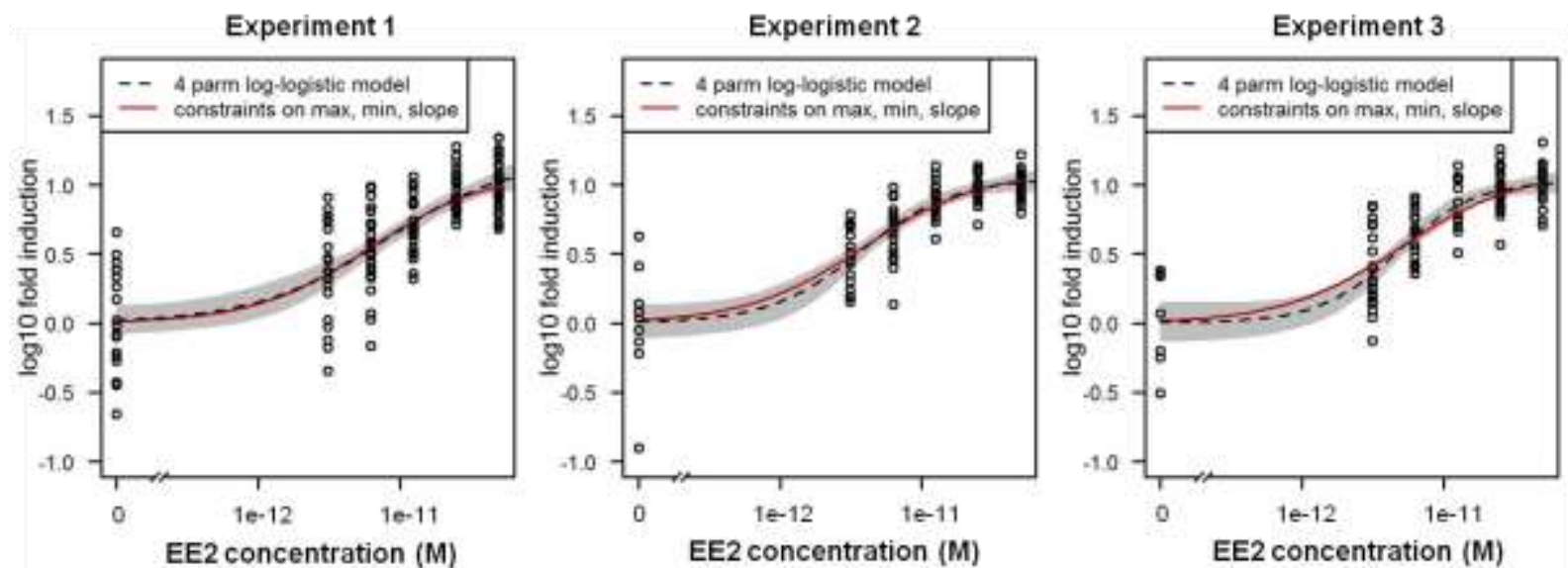
Supplemental figure 3
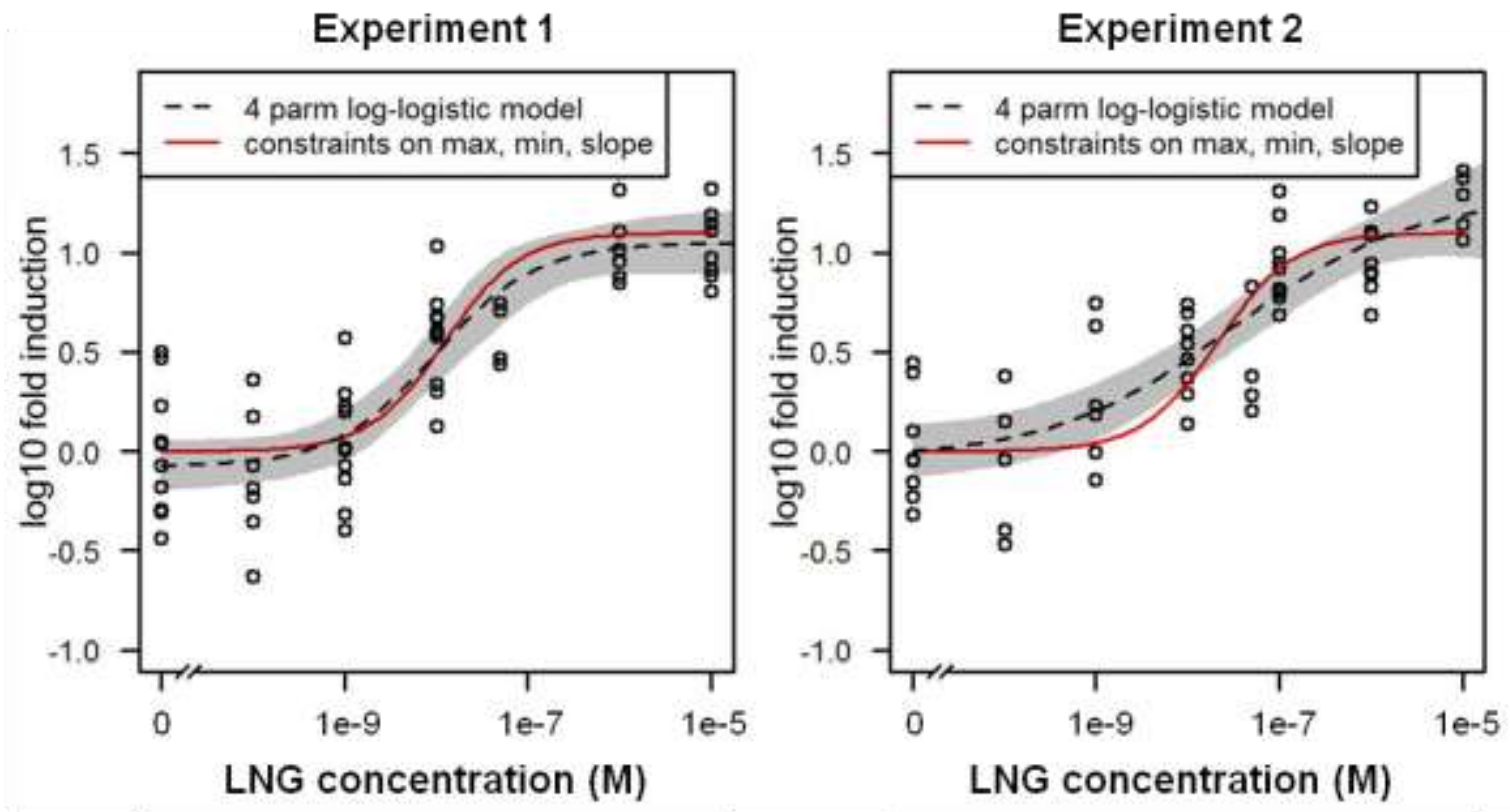
Supplemental Table 1: Experimental ray design for the assessment of the effects of ethinylestradiol (EE2) and levonorgestrel (LNG) alone and in mixtures on the expression of GFP in the brain of cyp19alb-GFP transgenic zebrafish line.

\begin{tabular}{|l|l|l|l|}
\hline Condition & {$[\mathrm{EE} 2](\mu \mathrm{M})$} & {$[\mathrm{LNG}](\mu \mathrm{M})$} & Ray \\
\hline 1 & 0 & 0 & $/$ \\
\hline 2 & $1.00 \mathrm{E}-04$ & 0 & $1: 0$ \\
\hline 3 & $2.50 \mathrm{E}-05$ & 0 & $1: 0$ \\
\hline 4 & $6.25 \mathrm{E}-06$ & 0 & $1: 0$ \\
\hline 5 & $1.56 \mathrm{E}-06$ & 0 & $1: 0$ \\
\hline 6 & $3.91 \mathrm{E}-07$ & 0 & $1: 0$ \\
\hline 7 & $7.50 \mathrm{E}-05$ & 0.075 & $3: 1$ \\
\hline 8 & $1.88 \mathrm{E}-05$ & 0.0188 & $3: 1$ \\
\hline 9 & $4.69 \mathrm{E}-06$ & 0.00469 & $3: 1$ \\
\hline 10 & $1.17 \mathrm{E}-06$ & 0.00117 & $3: 1$ \\
\hline 11 & $2.93 \mathrm{E}-07$ & 0.000293 & $3: 1$ \\
\hline 12 & $5.00 \mathrm{E}-05$ & 0.15 & $1: 1$ \\
\hline 13 & $1.25 \mathrm{E}-05$ & 0.0375 & $1: 1$ \\
\hline 14 & $3.13 \mathrm{E}-06$ & 0.00938 & $1: 1$ \\
\hline 15 & $7.81 \mathrm{E}-07$ & 0.00234 & $1: 1$ \\
\hline 16 & $1.95 \mathrm{E}-07$ & 0.000586 & $1: 1$ \\
\hline 17 & $2.50 \mathrm{E}-05$ & 0.225 & $1: 3$ \\
\hline 18 & $6.25 \mathrm{E}-06$ & 0.0563 & $1: 3$ \\
\hline 19 & $1.56 \mathrm{E}-06$ & 0.0141 & $1: 3$ \\
\hline 20 & $3.91 \mathrm{E}-07$ & 0.00352 & $1: 3$ \\
\hline 21 & $9.77 \mathrm{E}-08$ & 0.000879 & $1: 3$ \\
\hline 22 & 0 & 0.3 & $0: 1$ \\
\hline 23 & 0 & 0.075 & $0: 1$ \\
\hline 24 & 0 & 0.0188 & $0: 1$ \\
\hline 25 & 0 & 0.00469 & $0: 1$ \\
\hline 26 & 0 & 0.00117 & $0: 1$ \\
\hline & & & \\
\hline
\end{tabular}

